\title{
Content analysis of the reflection of media literacy in communication curricula of select Nigerian universities
}

\author{
Elizabeth Titilayo Aduloju ${ }^{1}$
}

Department of Communication Studies, Catholic Institute of West Africa, Nigeria

DOI: $10.30547 /$ worldofmedia.3.2019.3

\begin{abstract}
Media literacy enables people to interpret and make informed judgments as users of digital technology sources, as well as to become producers of media contents in their own right. However, many Nigerian universities are not aware of this literacy or have not included it in their curricula. This study analysed the media-literacy content in curricula of nine select universities in Africa's most populous nation: Nigeria. Some key findings revealed that: (a) media-literacy courses proper were not on the curricula; (b) media-literacy-related courses, which stood as proxies, accounted for about two per cent of the curricula; and (c) media-literacy-related courses were available to students only as electives. The present research indicates that media-literate students tend to be skilled in accessing information about their health, environment, education and work. They would also be able to evaluate media content critically and to make informed decisions as users of digital technology sources, as well as to becoming producers of media contents in their own right. Based on the accumulated skills of media literacy for contemporary young people, it was recommended that communications programmes redesign their curricula to include media literacy and related courses. Also, communication educators should be more receptive to the importance of media literacy skills in the education of their students.
\end{abstract}

\section{Keywords}

Communication curricula, digital era, digital literacy, media content, media literacy, media literacy skills, Nigerian universities, students.

\section{${ }^{1}$ Corresponding author:}

Elizabeth Titilayo Aduloju, Department of Communication Studies, Catholic Institute of West Africa, Port Harcourt, Nigeria.

Email: taduloju@yahoo.com 


\section{Introduction}

With the recent development of the information era, the Nigerian society is experiencing various changes whereby people, particularly young people, have unfettered access to a plethora of information and freely express themselves through new media. The advent of new media technologies continues to pose substantial challenges and risks to the 21st century youth, especially in the use of new media technology (Aduloju, 2017). In other words, it becomes clearer that they influence both the cultural and moral values of the current century youth when considering the influence of the ever-growing and expanding social networking sites on the Internet. In this way, the current students and youth generally are overwhelmed every day with media contents that shape their lives in different ways. Nevertheless, they often lack the ability and skills to decode the inherent meaning(s) of the media message(s). Given these current media and social atmospheres in Nigeria, a relevant media literacy would be essential to empowering people especially the young people with critical thinking and media skills.

This is why Avery (2007), Jenkins (2006, 2008) argue that, in the light of the media-saturated nature of modern life, it has been widely acknowledged that today's students need to develop new media or digital related competencies that will prepare them to live and participate in the world of the present and future. In other words, in the 21 st century, it is fundamental that all individuals develop the understanding and capability of creatively expressing their ideas through multiple forms, including multimedia. This means that media literacy has come to the fore and is a fundamental part of the work needed to achieve a media and information society capable of promoting a professional and sustainable community. Beyond the benefits of media composition and creative expression, the skills students develop through media production are marketable and increasingly being integrated into courses with a focus on professional development or applied discipline research experiences.

This is the reason the media literacy or digital literacy movement was developed to assist individuals of all ages in acquiring the competencies needed to fully participate in the modern world of media convergence (Schmidt, 2012). Corroborating this, Liang (2013) points out that media literacy can enable students to change from being passive information receivers to information creators and critical receivers. Such a student-centred orientation would, on the one hand, transform Nigerian education on the cultural level and, on the other hand, would ultimately influence the educational practice in the Nigerian society more broadly. Thus, media literacy is even more vital to today's university 
students as more and more of them have practical access to a variety of media (old and new) both at home and in school.

No doubt, media/digital literacy enables people to interpret and make informed judgments as users of digital technology sources, as well as to become producers of media contents in their own right. It leads the media literate students to the ability to access information about their health, their environment, their education and work. Supporting this view, Aduloju (2017) argues that those who are opened to media literacy are empowered to evaluate media contents critically and to make informed decisions as consumers and producers (prosumers) of media contents. Unfortunately, despite all the potentials of media literacy for students and young people, in particular, many Nigerian universities are not aware of this literacy or have not yet included it in their curricula. Thus, there is a need to develop these new skills and competencies among Nigerian university students to allow them to use more modern media technologies effectively and productively. This study, therefore, analyses the content of some curricula in Nigerian universities to find out the reflection of media literacy and related courses within the curricula.

\section{Objectives of the study}

The study aims to:

1. Find out the level of awareness of media literacy as a course among the universities in Southwest, Nigeria;

2. Determine the extent of the refection of media literacy as a course in Southwest universities' curricula;

3. Investigate the extent to which the universities' curricula in Southwest, Nigeria reflect other media literacy-related courses;

4. Explore ways in which media literacy can be incorporated into the curricula of universities in Nigeria.

\section{The concept of media literacy}

There have been various arguments on what the meaning of media literacy should be. Buckingham (2006) refers to it as 'a set of skills that enables individuals to operate effectively in information retrieval task in the technologyoriented environment'. Aririguzoh (2007) sees media literacy as 'the ability to access, analyse, evaluate and communicate information to the media audience through a variety of channels including print and non-print'. She explains further that it is a literacy that involves the systematic study of the media and their operations in our socio-political systems as well as contributing to 
the development and maintenance of our culture. It is the information and communication skills that are needed to make citizens more competent. In other words, it is the ability to read what the print media offer, see what the visual media present as well as hear what the aural media announce. According to the EU's Report on Formal Media Education in Europe (Hartai, 2014), the concept of media literacy is nowadays predominantly defined in policy, pedagogic, research, and public discourse as the ability to '[1] access the media, [2] understand and to critically approach different aspects of media contents and institutions, and [3] to create communication in a variety of contexts'. In short, according to Gallagher and Magid (2017), media literacy is the ability to think critically about the information you consume and create. It includes the ability to distinguish fact from opinion and to understand how media can sometimes be used to persuade people. This approach to media literacy, firstly introduced in The Aspen Institute Report of the National Leadership Conference on Media Literacy (Aufderheide, 1992), describes media literacy partly as the ability to use and understand media, as a means of self-protection and safe media choices, and partly as the ability to create media in all format, leaning towards the idea of self-empowerment, self-expression. It stresses that media literacy will bring about an active youth with informed, moral, and legal choices. In other words, specific skills have been identified as needed to be competent in a digital age.

Since Article 19 of The Universal Declaration of Human Rights (UN, 1989) states that everyone has the right and freedom 'to seek, receive and impart information and ideas through any media and regardless of frontiers', the UN holds that media literacy is 'essential to empower citizenries all around the world to have the full benefits of this fundamental right' (UNESCO, 2011). Asserting media literacy as a human right, a 'matter of inclusion and citizenship in today's information society' (European Commission, 2011a), has brought UN's and EU's attention to a need for strategic media education as a compulsory aspect of schooling. Media literacy is, therefore, a response to the changing nature of information in our modern society. It addresses the skills students need to be taught in the schools to enable them to evaluate the media wisely. Additionally, competent citizens must possess these skills to consume or create information in their homes and offices, and the abilities workers must acquire in this new millennium as globalisation takes over the world economy (Aririguzho, 2007). Thus, a media literate person is a 'person who can evaluate and use information critically from a relevant and authoritative source online' (Buckingham, 2006). 


\section{The necessity of media literacy for students}

Reading and writing have been valued as the primary means of communicating and understanding history, cultural traditions, political and social philosophy and the news of the day since the invention of moveable type. In more recent times, traditional literacy skills ensured that individuals could participate fully as engaged citizens and functioning adults in society (Dasgupa, 2013). Today, the definition of literacy is much broader. It takes into account the fact that people now live in a multimedia environment in which most of the information is delivered in a vibrant and intricate combination of words, images, and sounds. In addition to this, social networking sites have become the most popular online activity of recent, with Facebook claiming more than 500 million users (Wortham, 2010) and Twitter claiming 105 million users (Chacksfield, 2010) and the trend continues daily. In view of the mediasaturated nature of the digital era, it has been widely acknowledged that the contemporary young people that are aptly called the 'digital natives' (Prensky, 2003) need to develop new media-related competencies that will prepare them to live and participate in the world of the present and future (Avery, 2007). Thus, the responsibility for developing young people especially, for living and learning in a global culture that is increasingly connected through multimedia and influenced by powerful images, words and sounds are shared by different stakeholders, such as families, schools and all community institutions (Aduloju, 2017).

The 21st century is a media inundated, technologically dependent and globally connected world. Knllener and Share (2007) believe that the contemporary young people live in a world of multimedia where the majority of information they receive comes less often from the print source and more typically from highly constructed visual images, complex sound arrangement and multiple media formats. Specifically, the revolution that new technologies have brought about in every field is urging a new vision in the general formation and education of young people and the youth generally (Aduloju, 2017). The present technological revolution, however, brings to the fore, more than ever, the role of media like television, music, films advertising, as the new media particularly the Internet, rapidly and radically absorbs these conventional forms and creates an ever-evolving cyber-space, cyber-community and emergent forms of culture and pedagogy (Kellner \& Share, 2007).

Media literacy aims at:

i) increasing audience knowledge and understanding of the mass communication process and the mass media industries; 
ii) raising students' awareness of how they can interact to create media content and meaning;

iii) helping students become more skilled and knowledgeable media consumers.

Thus, media literacy matters because it arms the students with the needed skills for becoming informed and critical thinkers in a world where technology and media are ubiquitous, helping to immunise young people against undue persuasion and false information (Gallagher \& Magid, 2017). This is precisely what media literacy will help in addressing. In simple terms, the students will be more informed in terms of deciphering the right media content.

On the importance of media literacy for young people, Hobbs (2010) stresses that 'when people have media literacy competencies, they recognise personal, corporate and political agendas and are empowered to speak out on behalf of missing voices and omitted perspectives in our communities'. According to the European Charter of Media Literacy, there are seven areas of competencies or skills that are related to media literacy. These are:

(i) effective use of media technologies to access, store, retrieve and share content to meet individual and community needs and interests;

(ii) accessing and making informed choices about, a wide range of media forms and content from different cultural and institutional sources;

(iii) understanding how and why media message is produced;

(iv) critically analysing the techniques, languages and conventions used by the media and the messages they convey;

(v) creative use of the media to express and communicate ideas, information and opinions;

(vi) identifying, avoiding and/or challenging, media contents and services that may be unsolicited, offensive or harmful;

(vii) making efficient usage of the media in the practice of democratic rights and civil responsibilities (Perez-Tornero, 2008).

Looking at these areas of competencies, Adekunle (2017) argues for the inclusion of media literacy in the curricula of tertiary institutions in Nigeria, when he states that: 'In increasingly complex multicultural societies, education must enable us to acquire the intercultural competencies that will permit us to live together despite cultural differences. We need media literacy in our curriculum among other things; to enhance education outcomes by equipping citizens with competencies necessary to participate fully in political, economic, and social life'. 
To further justify the need for inclusion of media literacy in Nigerian curriculum, Olushola (2017) asserts that the youths quest for knowledge has gone beyond reading and writing skills, and needed a necessary tool that will enable them in analysing, understanding and using effectively the deluge of information they receive today.

Based on the above media literacy skills, it is indisputable that the new media literacy has several potentials that could develop and empower Nigerian university students and other young people. However, Bekkhus and Zacchetti (2010) point to the fact that these skills are fundamental in the lives of the youths but equally essential for other categories of adults - older adults, parents, teachers and media professionals - because these skills are needed for full participation in digital society as well. They are also part of a broader set of skills and competencies that are required for effectiveness and efficiency in the contemporary century (Aduloju, 2017).

\section{Methodology}

The present study was conducted using the content analysis method, which is applied in terms of research goals because its results could be used by Southwest university stakeholders and other tertiary institutions. The study population consisted of nine universities which were divided into three groups. The first group included three state universities (Adekunle Ajasin University, Akungba, Ondo State; Lagos State University, Ojo, Lagos State; and Olabisi Onabanjo University, Ago-Iwoye, Ogun State); the second group included three private universities (Afe Babalola University, Ado - Ekiti, Ekiti State; Joseph Ayo Babalola University, Ikeji - Aragbeji, Osun State; and Covenant University, Ota, Ogun State), the third group included three federal universities (Federal University Oye, Oye - Ekiti, Ekiti State; University of Ibadan, Ibadan, Oyo State; and National Open University of Nigeria, Ikeja, Lagos State). All the nine universities were from the Southwest geopolitical zone in Nigeria. Nine handbooks and curricula of undergraduate level for 2017/2018 academic session of the communication departments in the selected schools were collected and analysed to generate the data for this study. In this research, the purposive sampling method was used to select the universities. The reason for this was that the selected universities were the ones floating communication programmes at the time of conducting this study. The research tools in this study were a semi-structured telephone interview and a content analysis checklist. 
This study used a summative qualitative content analysis approach. Summative qualitative content analysis approach utilises the counting of manifest content and latent meanings and themes to explore the usage of items in the text (Hsieh \& Shannon, 2016). The validity of the tool was determined by using content validity, and the checklist was provided by an educational specialist who approved it after minor corrections. William Scott's method was used for the reliability of the study, where the content of the curricula was analysed by the researcher and an expert familiar with the content analysis method. An agreement coefficient of $84 \%$ was obtained. The unit of analysis in this research was words and courses in the undergraduate curricula of communication departments in the sampled universities. Therefore, to achieve the aim of the study, after analysing the contents of the curricula of the undergraduate curriculum of each school, tables were presented for the frequencies of each construct and its subcomponents.

\section{Data presentation and analysis}

The content analysis of the reflection of media literacy and related courses in the undergraduate's curricula of communication departments of nine universities in Southwest, Nigeria is presented below.

Table 1

Content analysis of media literacy and related courses in the Department of Linguistics and Communication Studies

(Adekunle Ajasin University)

\begin{tabular}{|c|c|c|c|c|}
\hline $\begin{array}{c}\text { No of } \\
\text { communication } \\
\text { courses }\end{array}$ & $\begin{array}{c}\text { No of media } \\
\text { literacy } \\
\text { courses }\end{array}$ & $\begin{array}{c}\text { No of ICT/ } \\
\text { related } \\
\text { courses }\end{array}$ & $\begin{array}{c}\text { Percentage } \\
\text { of media } \\
\text { literacy } \\
\text { courses }\end{array}$ & $\begin{array}{c}\text { Percentage } \\
\text { of ICT/ } \\
\text { related } \\
\text { courses }\end{array}$ \\
\hline 56 & 0 & 2 & 0 & 4 \\
\hline
\end{tabular}

The data shows that in the Department of Linguistics and Communication Studies, of Adekunle Ajasin University, a total number of 56 courses are offered at the undergraduate level. Out of the 56 courses, $0 \%$ is media literacy oriented while only $4 \%$ is devoted to ICT and other related courses. The data imply that the department has not given due attention to media literacy courses. 
Table 2

Content analysis of media literacy and related courses in the Department of Mass Communication

(Lagos State University)

\begin{tabular}{|c|c|c|c|c|}
\hline $\begin{array}{c}\text { No of } \\
\text { communication } \\
\text { courses }\end{array}$ & $\begin{array}{c}\text { No of media } \\
\text { literacy } \\
\text { courses }\end{array}$ & $\begin{array}{c}\text { No of ICT/ } \\
\text { related } \\
\text { courses }\end{array}$ & $\begin{array}{c}\text { Percentage } \\
\text { of media } \\
\text { literacy } \\
\text { courses }\end{array}$ & $\begin{array}{c}\text { Percentage } \\
\text { of ICT/ } \\
\text { related } \\
\text { courses }\end{array}$ \\
\hline 86 & 0 & 2 & 0 & 2 \\
\hline
\end{tabular}

The results in the above table show that in the Department of Mass Communication of the University of Lagos, a total number of 86 courses are offered at the undergraduate level. Out of these 86 courses, only $2 \%$ is ICT oriented courses while none is media literacy inclined. Thus, the results indicate that the department does not give much emphasis to media literacy and ICT courses.

Table 3

Content analysis of media literacy and related courses in the Department of Mass Communication

(Olabisi Onabanjo University)

\begin{tabular}{|c|c|c|c|c|}
\hline $\begin{array}{c}\text { No of } \\
\text { communication } \\
\text { courses }\end{array}$ & $\begin{array}{c}\text { No of media } \\
\text { literacy } \\
\text { courses }\end{array}$ & $\begin{array}{c}\text { No of ICT/ } \\
\text { related } \\
\text { courses }\end{array}$ & $\begin{array}{c}\text { Percentage } \\
\text { of media } \\
\text { literacy } \\
\text { courses }\end{array}$ & $\begin{array}{c}\text { Percentage } \\
\text { of ICT/ } \\
\text { related } \\
\text { courses }\end{array}$ \\
\hline 57 & 0 & 3 & 0 & 5 \\
\hline
\end{tabular}

The data on the above table show that in the Department of Mass Communication, a total of 57 courses are offered at the undergraduate level. Out of the 57 courses, $0 \%$ of media literacy oriented courses make up the curriculum while $5 \%$ of the total courses is ICT inclined. The results show that media literacy and other related courses in this school have not been given due attention to in the undergraduates' curriculum. 
Figure 1

Summary of the content analysis of media literacy/related courses in the curricula of state universities of Southwest, Nigeria

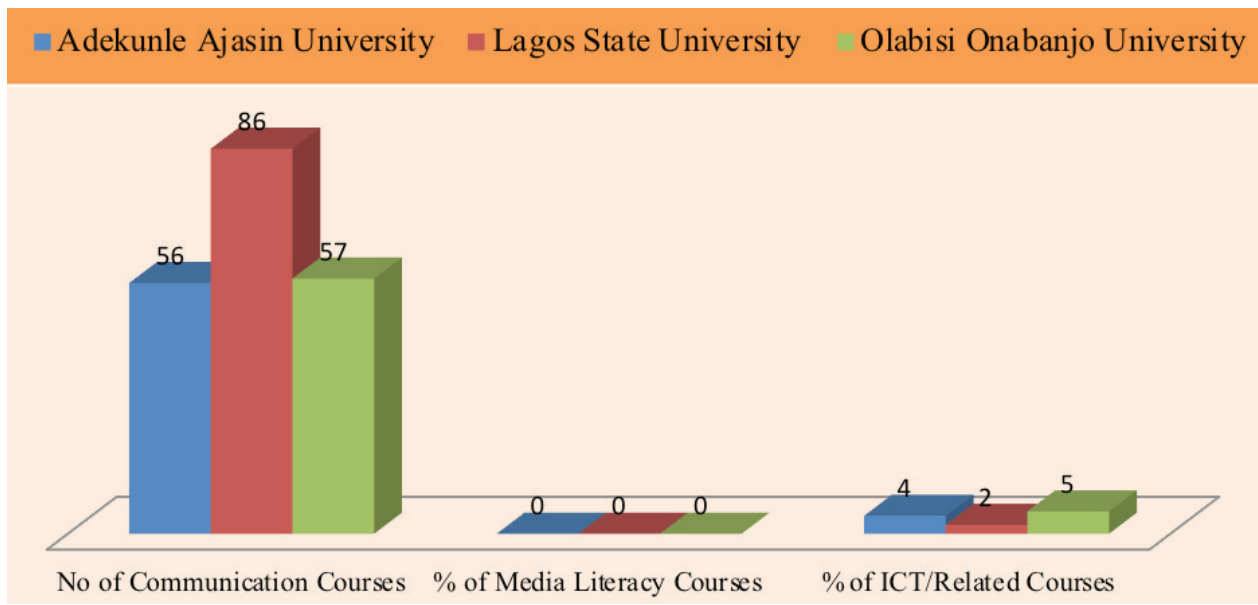

Table 4

Content analysis of media literacy and related courses in the Department of Media and Communication Studies

(Afe Babalola University, Ado Ekiti)

\begin{tabular}{|c|c|c|c|c|}
\hline $\begin{array}{c}\text { No of } \\
\text { communication } \\
\text { courses }\end{array}$ & $\begin{array}{c}\text { No of media } \\
\text { literacy } \\
\text { courses }\end{array}$ & $\begin{array}{c}\text { No of ICT/ } \\
\text { related } \\
\text { courses }\end{array}$ & $\begin{array}{c}\text { Percentage } \\
\text { of media } \\
\text { literacy } \\
\text { courses }\end{array}$ & $\begin{array}{c}\text { Percentage } \\
\text { of ICT/ } \\
\text { related } \\
\text { courses }\end{array}$ \\
\hline 55 & 1 & 2 & 2 & 4 \\
\hline
\end{tabular}

The data in the above table show the Media and Communication Studies Department of the Afe Babalola University with a total number of 55 courses that are offered at the undergraduate level. Out of these 55 courses, only $2 \%$ and $4 \%$ of them are media literacy and ICT related courses in the curriculum. The data imply that the importance the department gives to both ICT and media literacy courses is very low compared with emphasis on general courses. 
Table 5

Content analysis of media literacy and related courses in the Department of Mass Communication (Joseph Ayo Babalola University)

\begin{tabular}{|c|c|c|c|c|}
\hline $\begin{array}{c}\text { No of } \\
\text { communication } \\
\text { courses }\end{array}$ & $\begin{array}{c}\text { No of media } \\
\text { literacy } \\
\text { courses }\end{array}$ & $\begin{array}{c}\text { No of ICT/ } / \\
\text { related } \\
\text { courses }\end{array}$ & $\begin{array}{c}\text { Percentage } \\
\text { of media } \\
\text { literacy } \\
\text { courses }\end{array}$ & $\begin{array}{c}\text { Percentage } \\
\text { of ICT/ } \\
\text { related } \\
\text { courses }\end{array}$ \\
\hline 59 & 0 & 3 & 0 & 5 \\
\hline
\end{tabular}

The data in the above table show that in the Department of Mass Communication, a total number of 59 courses are offered at the undergraduate level. Out of the 59 courses, only $5 \%$ of ICT oriented courses make up the curriculum with $0 \%$ reflection of media literacy as a course in the curriculum. This implies that the department does not attach much importance to media literacy and other related courses.

Table 6

Content analysis of media literacy and related courses in the Department of Mass Communication

(Covenant University)

\begin{tabular}{|c|c|c|c|c|}
\hline $\begin{array}{c}\text { No of } \\
\text { communication } \\
\text { courses }\end{array}$ & $\begin{array}{c}\text { No of media } \\
\text { literacy } \\
\text { courses }\end{array}$ & $\begin{array}{c}\text { No of ICT/ } \\
\text { related } \\
\text { courses }\end{array}$ & $\begin{array}{c}\text { Percentage } \\
\text { of media } \\
\text { literacy } \\
\text { courses }\end{array}$ & $\begin{array}{c}\text { Percentage } \\
\text { of ICT/ } \\
\text { related } \\
\text { courses }\end{array}$ \\
\hline 84 & 0 & 5 & 0 & 6 \\
\hline
\end{tabular}

The data in the above table show that in the Department of Mass Communication at the Covenant University, a total number of 84 courses are offered at the undergraduate level. Out of these 84 courses, it is only $6 \%$ of ICT/Related oriented courses that make up the curriculum while there was no reflection of media literacy in the whole syllabus. This data indicates that the department has not placed adequate importance on media literacy and other related courses. 
Figure 2

Summary of the content analysis of media literacy/related courses in the curricula of private universities of Southwest, Nigeria

\section{Afe Babalola University $\quad$ Joseph Ayo Babalola University $\square$ Covenant University}

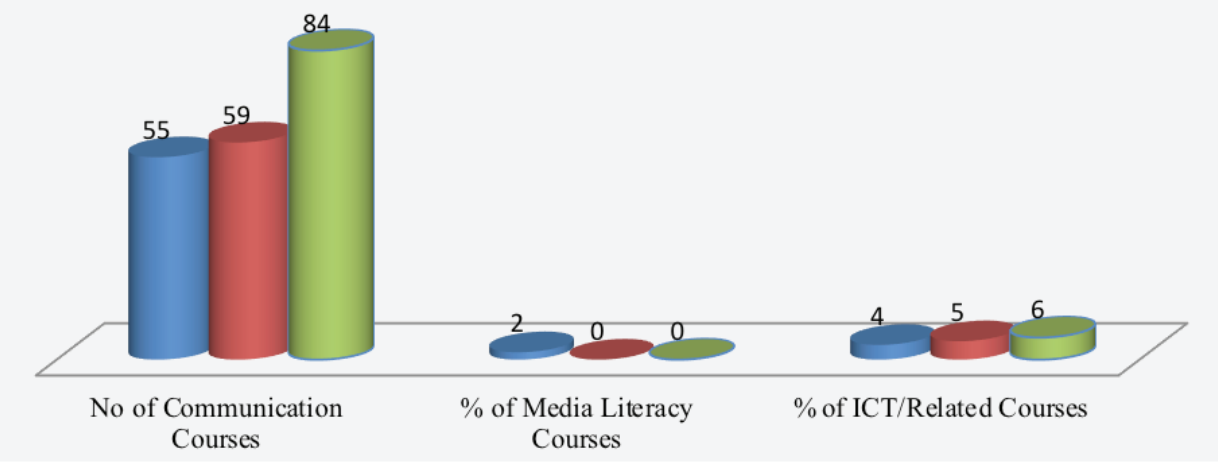

Table 7

Content analysis of media literacy and related courses in the Department of Mass Communication (Federal University Oye Ekiti)

\begin{tabular}{|c|c|c|c|c|}
\hline $\begin{array}{c}\text { No of } \\
\text { communication } \\
\text { courses }\end{array}$ & $\begin{array}{c}\text { No of media } \\
\text { literacy } \\
\text { courses }\end{array}$ & $\begin{array}{c}\text { No of ICT/ } \\
\text { related } \\
\text { courses }\end{array}$ & $\begin{array}{c}\text { Percentage } \\
\text { of media } \\
\text { literacy } \\
\text { courses }\end{array}$ & $\begin{array}{c}\text { Percentage } \\
\text { of ICT / } \\
\text { related } \\
\text { courses }\end{array}$ \\
\hline 62 & 0 & 2 & 0 & 3 \\
\hline
\end{tabular}

The data in the above table show that in the Department of Mass Communication, a total number of 68 courses are offered at the undergraduate level. Out of the 68 courses, only $3 \%$ of ICT oriented courses constitute the curriculum with no traces of media literacy or related courses in the curriculum. The data imply that the department does not pay much attention to media literacy and other related courses in the curriculum. 
Table 8

Content analysis of media literacy and related courses in the Department of Mass Communication and Language Arts

(University of Ibadan)

\begin{tabular}{|c|c|c|c|c|}
\hline $\begin{array}{c}\text { No } \\
\text { of communication } \\
\text { courses }\end{array}$ & $\begin{array}{c}\text { No of } \\
\text { media } \\
\text { literacy } \\
\text { courses }\end{array}$ & $\begin{array}{c}\text { No of ICT/ } \\
\text { related } \\
\text { courses }\end{array}$ & $\begin{array}{c}\text { Percentage } \\
\text { of media } \\
\text { literacy } \\
\text { courses }\end{array}$ & $\begin{array}{c}\text { Percentage } \\
\text { of ICT/ } \\
\text { related } \\
\text { course }\end{array}$ \\
\hline 59 & 0 & 0 & 0 & 0 \\
\hline
\end{tabular}

The data in the above table show that in the Department of Communication and Language Arts at the University of Ibadan, a total number of 59 courses are offered at the undergraduate level. Out of the 59 courses, $0 \%$ is given to both media literacy and ICT oriented courses in the curriculum. Here, the data indicate that the department has not placed significant value on media literacy and other related courses.

Table 9

Content analysis of media literacy and related courses in the Department of Mass Communication (National Open University of Nigeria)

\begin{tabular}{|c|c|c|c|c|}
\hline $\begin{array}{c}\text { No of } \\
\text { communication } \\
\text { courses }\end{array}$ & $\begin{array}{c}\text { No of media } \\
\text { literacy } \\
\text { courses }\end{array}$ & $\begin{array}{c}\text { No of ICT/ } \\
\text { related } \\
\text { courses }\end{array}$ & $\begin{array}{c}\text { Percentage } \\
\text { of media } \\
\text { literacy } \\
\text { courses }\end{array}$ & $\begin{array}{c}\text { Percentage } \\
\text { of ICT/ } \\
\text { related } \\
\text { courses }\end{array}$ \\
\hline 64 & 1 & 4 & 2 & 6 \\
\hline
\end{tabular}

The results in the above table show that in the Department of Mass Communication, at the National Open University of Nigeria, a total number of 64 courses are offered at the undergraduate level. Out of the 64 courses, only $2 \%$ of media literacy oriented courses, and $6 \%$ of ICT/related courses constitute the curriculum. This data imply that the department has not paid due attention or placed sufficient importance to media literacy and other related courses. 
Figure 3

\section{Summary of the content analysis of media literacy/related courses in the curricula of federal universities of Southwest, Nigeria}

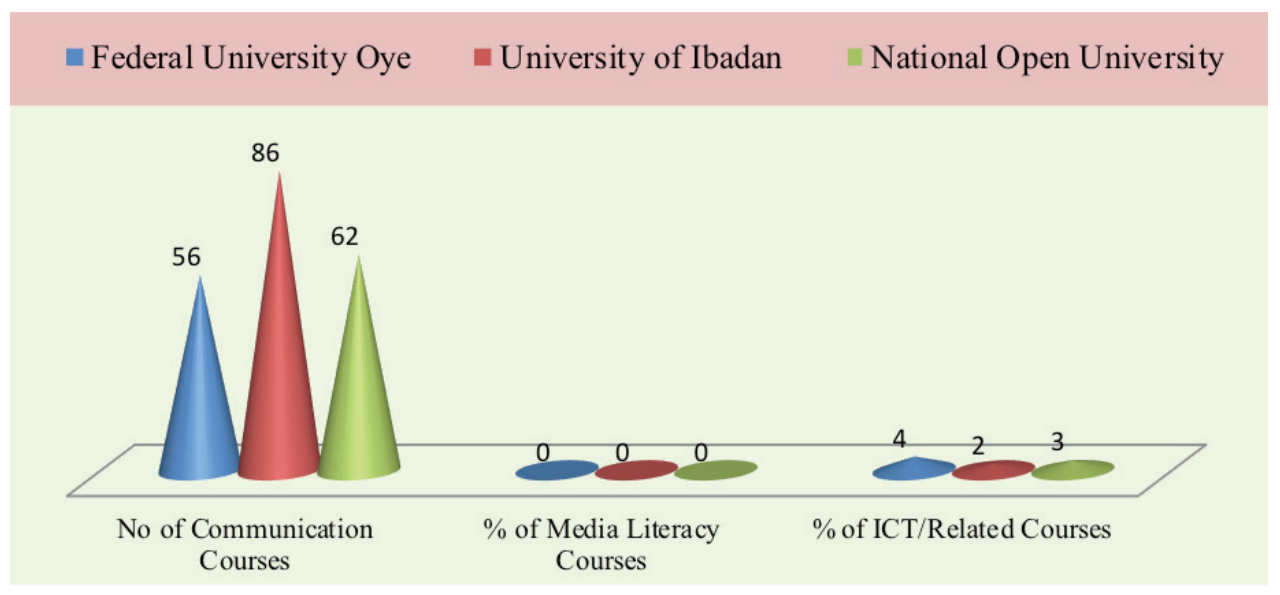

\section{Discussion of findings}

Generally, the analysis of data for this study suggests that university students in the study area are not exposed to media literacy and other related courses. The responses to the telephone interview by the heads of communication departments of the sampled schools revealed that most of them were not aware of media literacy as a course in higher institutions. Some have very scanty knowledge about the course, and even the few that know about it and its imports are yet to include it in their programmes. In other words, the tertiary institutions in Nigeria are yet to incorporate media literacy as a course in the programmes offered at the undergraduate level. For instance, the analysis of the findings shows a range of $0 \%$ to $2 \%$ of media literacy and other related courses that are being taught in the select universities in Nigeria. This implies that media literacy or digital literacy courses are not reflecting in the curricula or not sufficiently taught in the selected universities.

The analysis also reveals that some contents in the curricula that reflect ICT/ related courses are merely taken as electives or optional courses. Thus, the data in the tables and figures show the poor treatment given to media literacy, digital literacy and ICT courses in the curricula of Southwest, Nigerian universities. For illustration, out of the nine universities sampled, only Afe Babalola University, (private) and National Open Universities of Nigeria (federal) have attempted to include a related course in media literacy (Film Criticism) in their curricular with 
only $2 \%$ of the total courses respectively. The findings of the analysis also show that State Universities have not included either media literacy or any related courses in their curricula. Besides, among all the universities, only Covenant University (private) and National Open University of Nigeria (federal) have incorporated up to 6\% ICT or related courses in their curricula. Although this percentage is comparatively high compared to others, it is still very low when compared with other higher institutions of learning in advanced countries. Hence, one can say that the provision of media literacy content, in particular, is yet to be realised in Nigerian universities or adopted in the Nigerian educational system like other advanced countries.

Such findings are not, however, entirely surprising. Instead, the analysis and data gathered in the study confirm what other media scholars have suggested: the implementation of media literacy curricula in post-secondary higher education is still in its infancy stages (Aufderheide, 1993; Brown, 1991; Stuhlman \& Silverblatt, 2007). Similarly, Wulff (1997) avers that, 'In higher education, the progress towards the incorporation of media literacy as an essential ability in higher education appears minimal'. Several reasons may be responsible for the weak reflection of media literacy in the Nigerian universities' curricula such as confusion among mass communication departments regarding what media literacy involves and a general perception that students are 'digital natives' who do not require media training.

Additionally, as observed in the curricula of the universities sampled, some of the challenges the departments of communication studies face today are the growing number of general studies courses such as courses in French, citizenship education, peace and conflict studies, entrepreneurship studies, history and philosophy science, etc. Some private universities include in their curricula the study on agricultural science and food security, language acquisition and the study of the history of the proprietor of the university. No doubt, some of these general courses are useful; nevertheless, they do not have direct bearing with communication studies. One can then say that rather than filling the curricula with many of these general courses, media literacy and other related courses that have direct bearing with communication, the students and the society at large should be integrated because of their accumulated values to the contemporary young people.

It is true that other courses in other areas should also be taught and taught well. However, when we evaluate the importance of the skills of media literacy, we realise how essential it is in the development of the 21st century youth/ 
students in the country. Such as Edarabia (n.d) points out that the skills of media literacy should help the future generation to be able to analyse, interpret and understand the content published by media and not get misled. Corroborating on the importance of media literacy to the young people, Hobbs (2010) argues that 'when people have media literacy competencies, they recognise personal, corporate and political agendas and are empowered to speak out on behalf of missing voices and omitted perspectives in our communities'. Hence, media literacy has become a moral obligation for education institutions to help the young minds develop an informed and critical understanding of the nature of new media, the techniques used by then and the impact of these in their lives. Therefore, there is an urgent need to enrich the mass communication curricula with courses on media literacy, ICTs and other related courses and make them core courses. Arguing for the inclusion of media literacy education in the curricula of tertiary institutions in Nigeria, Adekunle (2017) states that: 'In increasingly complex multicultural societies, education must enable us to acquire the intercultural competencies that will permit us to live together despite cultural differences. We need media literacy in our curriculum among other things; to enhance education outcomes by equipping citizens with competencies necessary to participate fully in political, economic, and social life'.

In line with this, Yates (2001) points out that for many years, the notion of new media literacy has continued to emerge; nevertheless, it is now being 'marketed' as a new concept in its current structure. In other words, the idea of media literacy is being expounded as an innovation to prospective adopters. Nigeria educators, instructors, policymakers, interest groups should recognise the necessity to promote media knowledge in schools and among children and youths. Thus, Nigeria as a country, should see media literacy as a new concept that is being diffused into the educational milieu and adopt it in her educational system not only at the tertiary levels but also at the elementary levels because of the relevance of media literacy/education to the contemporary children and young people in general.

\section{Conclusion}

Curriculum development has always been challenged with the emergence of new ideas and perspectives on how to best train students. These new perspectives are not only brought about by the developments in information and communication technologies but also changes in the content and pedagogy of subject courses. The communication curricular at the undergraduate level in Nigeria is no exception, especially in the formation and training of the 21st century youth 
as future media practitioners. They are expected to be the game-changers in the promotion of responsible and critical media consumption and production of mediated contents. With the advances in information technologies, social networking sites and other digital formats, which have turned 21st century youth into digital natives, there is a need to review the existing curricula to make them more responsive to the needs of the current web generation. As future media practitioners, students need to access, understand, use and share required information responsibly and appropriately to promote a healthy media living for the individual and the society. This is why media literacy (education) in the communication curriculum is imperative. Thus, this study provides some new perspectives on integrating media literacy in the communication curriculum of the universities in Nigeria. The position of this study is that at least 30 percent of the curriculum contents of mass communication departments in Nigeria universities should be devoted to media literacy and other related courses.

\section{References}

ADEKUNLE, S. O. (2017). Promoting media and information literacy in Nigeria. Available from: https://en.unesco.org/news/promoting-media-andinformation-literacy-nigeria

ADULOJU, E. T. (2017). The new media literacy skills and the self-development among secondary school students in Ekiti State, Nigeria. Unpublished doctoral dissertation. University of Port Harcourt, Rivers State.

ADUM, A. N, OJIAKOR, O. E., \& OPARA, O. E. (2015). A discourse on child media literacy. Mgbakoigba: Journal of African Studies, 4, pp. 1-16.

ALAGARAN II, J. R. (2015). Explore, engage, empower model: Integrating media and information literacy (MIL) for sustainable development in communication education curriculum. In: J. Singh, A. Grizzle, S. J. Yee, \& S. H. Culver, Media and information literacy for the sustainable development goals. Sweden, The International Clearinghouse on Children, Youth and Media Nordicom, University of Gothenburg.

ARIRIGUZOH, S. A. (2007). Media literacy and the role of English Language in Nigeria. International Journal of Communication, 6, pp. 144-160.

AUFDERHEIDE, P. (1993). Aspen media literacy conference report-part II: Proceedings and next steps. Medialit. Available from: http://www.medialit.org

AVERY, R. K. (2007). The public broadcasting act of 1967: Looking ahead by looking back. Critical Studies in Mass Communication, 24(4), pp. 358-364. 
BEKKHUS, N. \& ZACCHETTI, M. (2011). A European approach to media literacy. International Journal of Learning and Media, 4(3-4). Available from http://ijlm.net/news/european-approach-media-literacy

BROWN, J. (1991). Television critical viewing skills education: Major media literacy projects in the United States and selected countries. Hillsdale, NJ, Lawrence Erlbaum.

BUCKINGHAM, D. (2006). Defining digital library: What people need to know about digital media? Digital Kompetanse, 4(1), pp. 263-276.

DALEY, E. (2003). Expanding the concept of literacy. Educause Review, 38(2), pp. 32-40.

DASGUPA, A. (2013). Review of centre for media literacy web-site (www. medialit.org). Choice: Current Reviews for Academic Libraries, 50(9), pp. 16191619.

EDARABIA, (n.d). How important is media literacy to students? Available from: https://www.edarabia.com/how-important-media-literacy-students/

European Commission (2011a). Culture and media: Media programme and media literacy. Brussels. Available from: http://www.un.org

European Commission (2011b). Testing and refining criteria to assess media literacy levels in Europe. Final report. Available from: http://www.eavi.eu/

GALLAGHER, K. \& MAGID, L. (2017). Parents and educator guild: Media literacy \& fake news. Massachusetts, ConnectSafely.

HARTAI, L. (2014). Report on formal media education in Europe (WP). EMEDUS: European Media Literacy Education Study. Brussels, European Union, Lifelong Learning Programme.

HSIEH, H. F. \& SHANNON, S. E. (2016). Three approaches to qualitative content analysis. Qual Health Res., 15(9), pp. 77-88.

HOBBS, R. (2010). Digital and media literacy: A plan of action. A white paper on the digital and media literacy recommendations of the knight commission on information needs of communities in democracy. The Aspen Institute, Communications and Society Programme.

JENKINS, H. (2006). Convergence culture: Where old and new media collide. New York, New York University Press.

JENKINS, H. (2008). Editorial. Convergence, 14(1), pp. 5-9.

KELLNER, D. \& SHARE, J. (2007). Critical media literacy, democracy, and the reconstruction of education. In: D. Macedo \& S. R. Steinberg, Media literacy: A reader. New York: Peter Lang, pp. 3-23.

LIANG, J. B. (2013). Integrating media education into the curriculum: What Chinese educators can learn from Ontario Education. A master's thesis submitted 
to the Department of Graduate and Undergraduate Studies in Education Faculty of Education, Brock University St. Catharines, Ontario, Canada.

MCDOUGALL, J., BERGER, R., FRASER, P., \& ZEZULKOVA, M. (2015). Media literacy, education \& (civic) capability: A transferable methodology. Journal of Media Literacy Education, 7(1), 4-17.

National Communication Association (1998). K-12 speaking, listening, and media literacy standards and competency statements. Washington, D.C., National Communication Association. Available from: http://www.natcom.org/NCA/ admin/index.asp?downloadid $=119$.

OLUSHOLA, M. (2017). Promoting media and information literacy in Nigeria. Available from: https://en.unesco.org/news/promoting-media-andinformation-literacy-nigeria

PEREZ-TORNERO, J. M. (2008). Media literacy: New conceptualisation, new approach. In: U. Carlsson, S. Tayie, G. Jacquinot-Delaunay, \& J. Tornero, Empowerment through media education: An intercultural dialogue. Sweden, The International Clearinghouse on Children, Youth and Media.

RIDA-E-FIZA, S., MUHAMMAD, F., FARIA, I., FARA, R., \& SHAMAS, U. (2015). Barriers in employment effective training and learning. Mediterranean Journal of Social Sciences, 6(3), pp. 240-250.

ROGERS, E. M. (1995). Diffusion of innovations. New York, Free Press.

ROGERS, E. M. (1996). Communication technologies: The new media in society. New York, Free Press.

SCHMIDT, H. (2012). Media literacy education at the university level. The Journal of Effective Teaching, 12(1), pp. 64-77.

SHELLY, G. B, CASHMAN, T. J, GUNTER, R. E., \& GUNTER, G. A. (2008). Integrating technology and digital media in the classroom. Boston, Thomas Course Technology.

STUHLMAN, L. \& SILVERBLATT, A. (2007). Media literacy in U.S. institutions of higher education: Survey to explore the depth and breadth of media literacy education. Available from: http://www.webster.edu/medialiteracy/

UNESCO (2011). Media and information literacy curriculum for teachers. Available from: http://www.unesco.org

UNESCO (2014). Paris declaration on media and information literacy. Available from: http://www.unesco.org

UNITED NATIONS (1989). Article 19 of the universal declaration of human rights. Available from: http://www.un.org 
WORTHAM, J. (2010). Facebook tops 500 million users. The New York Times, 22th July, 2010. Available from: http://www.nytimes.com/2010/07/22/ technology/22facebook.html

WULFF, S. (1997). Media literacy. In: W. G. Christ, Media education assessment handbook. Hillsdale, NJ, Lawrence Erlbaum Associates, pp. 123-142.

YATES, B. L. (2001). Media literacy and attitude change. Available from: http://www.westga.edu/ byates/media1.htm 